\title{
Generic and Specific Relevant Soft Skills for Increasing Competence of Vocational Teachers Candidates
}

\author{
Muhamammad Amin ${ }^{1}$, Salman Bintang ${ }^{2}$, and Adi Sutopo ${ }^{3}$ \\ \{aminunimed@unimed.ac.id\} \\ Pendidikan Teknik Elektro, Fakultas Teknik, Universitas Negeri Medan, Indonesia ${ }^{1}$, Teknik Elektro, \\ Fakultas Teknik, Universitas Negeri Medan,Medan, Indonesia ${ }^{2,3}$
}

\begin{abstract}
This study aims to find the attributes of soft skills both generic and specific that are relevant to be integrated in the lecture program in the Electrical Engineering Education. The soft skills attribute found is expected to be a supplement in lecture activities in order to produce graduates who have simultaneous competence between knowledge, attitudes, and skills. The data collection methods were carried out by: (1) identifying the types of attributes of soft skills based on local culture, which originated from 6 pillar of unimed character education, as well as attributes derived from the results of international studies; (2) conduct studies and groupings of all attributes that are generic and specific; (3) identify the characteristics of the course, especially those relating to the objectives and plans of lecture activities; (4) conduct a study of the relevance between the objectives and activities of lectures with attributes that can be integrated. The results show that there are 73 attributes that are generic and 56 that are specifically relevant to be mapped, distributed, and trained in each subject. Soft skills that will be trained in the first year are distributed in 22 courses, in the second year 22 courses, and in the third year are distributed in 18 courses.
\end{abstract}

Keywords: soft skills, competence, vocational teachers candidates.

\section{Introduction}

The perceived limitations in coaching competent teacher candidates, and teachers who have character at this time has become an urgent need. The teacher is the spearhead for quality human development, therefore repairs and improvements must be carried out immediately. In detail in the Government Regulation of the Republic of Indonesia No. 19/2005, concerning National Education Standards, specifically in article 28, emphasized that educators are learning agents who must have four types of competencies, namely pedagogic, personal, professional, and social competencies. In that context, the teacher's competence can be interpreted as the unanimity of knowledge, skills and attitudes that are realized in the form of intelligent and responsible actions that must be possessed by a teacher to assume the position of teacher as a profession [1] and [2].

The fact is that the problem of coaching vocational teacher candidates is still the actual problem faced by teacher training institutions today, especially in the education of prospective teachers in the field of electricity. Competencies of prospective teacher students tend to be more prominent in their pedagogical and professional competencies while personality and social competencies are still very lagging. To improve simultaneous competence for prospective teacher students, attributes of soft skills are needed as a supplement that is integrated in the curriculum to improve personality and social competence [3]. Soft skills attributes that are 
integrated should be based on needs, so that the learning process still maintains the student's socio-cultural situation [4].

Coaching vocational teacher candidates who have only been provided with the knowledge and skills in the form of hard skills, are not effective enough in solving problems in the learning process [5], therefore debriefing soft skills for prospective teachers is also very necessary as part of from the learning process so that it happens habitually for students as prospective teachers. To do learning with soft skills, it is necessary to develop learning by integrating the attributes of soft skills in lecture activities [6]. It should be realized that the attributes of soft skills that have been identified are quite varied, so that maximum efforts are needed in selecting and sorting out relevant attributes to be developed and integrated in the learning process. To find the attributes of relevant soft skills, it is necessary to study soft skills that develop based on the needs of the place where students socialize. This study becomes a reference in approaching the learning process, so that students who take part in learning are not alienated from their social environment. This is very important to do, so that the lectures in the lecture are truly grounded for students [7].

\section{Research Methods}

This study uses a qualitative approach. Stages of research activities include literature study activities, exploration of data collection, and verification of the attributes of soft skills for the needs of teachers, students and stakeholders. Literature study is used to find the types of attributes of soft skills based on expert views and research results. Exploration activities are carried out to find the types of attributes of soft skills derived from the 6 pillars of unimed character, as well as the types of attributes of soft skills originating from the local culture. Further verification activities are intended to verify the suitability of soft skills that have been identified with needs.

Literature study is carried out by tracing relevant sources, so that various types of attributes of soft skills are found which are the best practices by experts, as well as the findings of researchers from various countries. Literature search is done through sharing print media such as journals, textbooks, as well as guide books on the application of character learning from various countries. Search results are identified and grouped according to their general or specific nature. Grouping results are also carried out based on similarity to be reduced, so that the types of attributes that have similarities will be chosen which are more operational.

The exploration phase of the need for soft skills is carried out to find the attributes of soft skills that must be possessed by teacher candidates when teaching in Vocational High Schools. To find the types of attributes of soft skills originating from local culture, the research was conducted by interviewing, and document study to obtain the information needed. The collection of information is obtained from stakeholders as users of graduates, community leaders, and education figures in the North Sumatra region. The interview technique is used to explore the attributes of soft skills needed by the business world, and which become the habits and expectations of graduate users, both in the form of a value system, as well as the order of social life they use. The results of the interview are translated in the form of keywords that lead to the attributes of soft skills, and then recapitulated in the form of attributes of soft skills.

At the verification stage, the research was carried out by verifying the relevance level of the attributes of soft skills for vocational teachers. Verification is performed on the types of attributes that have been identified. Verification activities are carried out through delphi techniques and Forum Group Dicussion (FGD) activities. Verification activities involve subject lecturers and students in Unimed FT Electrical Engineering Education. Verification is done to determine the level of relevance of the attributes of each soft skill for the relevant teacher's needs to be integrated in each of the courses that will be taken by prospective teacher students.

\section{Result And Discussion}

The tabulation results of the attributes of soft skills that are found by source are 85 attributes that are generic and 59 types of attributes that are specific soft skills. However, after verification and validation, it was found 
that out of 85 attributes that were generic there were 12 types of attributes that were considered irrelevant, with reasons for being less operational, and duplicating / intersecting with other types of attributes. While 59 types of attributes that are specific, three types of attributes are not relevant, so that 73 types of attributes are considered relevant. In detail the results of identification of relevant attributes are outlined in Table 1.

Table 1. Number of Soft Skills Attributes Identified by Source

\begin{tabular}{|c|c|c|}
\hline \multirow[t]{2}{*}{ Source of Study } & \multicolumn{2}{|c|}{$\begin{array}{c}\text { Number of } \\
\text { Atribur based on } \\
\text { Nature }\end{array}$} \\
\hline & Generic & Specific \\
\hline $\begin{array}{l}\text { Local Culture of North } \\
\text { Sumatra }\end{array}$ & 11 & 33 \\
\hline $\begin{array}{l}\text { UNIMED Character } \\
\text { Education Pillar }\end{array}$ & 6 & 23 \\
\hline Spencer \& Spencer (1993) & 15 & \\
\hline Ramesh (2010) & 3 & \\
\hline $\begin{array}{l}\text { Ministeri of Higher } \\
\text { Education Malaysia } \\
\text { (2006) }\end{array}$ & 7 & \\
\hline $\begin{array}{l}\text { Research Results in the } \\
\text { United Kingdom, America } \\
\text { and Canada }\end{array}$ & 19 & \\
\hline Sailah (2008) & 12 & \\
\hline Jumlah & 73 & 56 \\
\hline
\end{tabular}

The initial identification of the attributes of soft skills originating from the local culture of North Sumatra found 11 types of attributes that are generic and four attributes that are specific. Based on searches conducted through ethnic groups in North Sumatra formulated 11 attributes of the most relevant and generic soft skills, including: (1) religious, (2) discipline, (3) visoner, (4) cooperation, (5 ) leadership and organization, (6) adaptable / flexible, (7) tolerant / friendly, (8) confident, (9) caring, (10) serving, and (11) honest. Apart from the 11 attributes that are generic, four attributes of specific soft skills are obtained, namely (1) oral communication, (2) written communication, (3) problem solving, (4) work responsibilities. The four attributes are also the results of an assessment of the attributes that are relevant for vocational teacher candidates in the North Sumatra region. These results are the results of an assessment of relevant attributes for vocational teacher candidates in the North Sumatra region. Furthermore, the results of the assessment of the 11 attributes that are generic are obtained a number of 29 attributes that are specific, so that the number of attributes that are specific from the local culture amount to 33 attributes. All attributes obtained are relevant as supplements that will be integrated in each appropriate course.

The results of the assessment of the 6 pillars of the character of UNIMED obtained 6 attributes that are generic, and each has a description of specific attributes so that a number of 26 attributes are obtained. The six character pillars built by the Unimed Institute consist of: trustworthy, respect, maintain justice, care, responsibility, and citizenship. To know that a prospective teacher can be trusted, then of course must have specific soft skills such as Honesty (not cheating, copying, or stealing), reliable (doing what is said), brave (doing the right thing), maintaining a good reputation, and obedient (standing with family, friends and country). To be able to respect, of course must be able to tolerate differences, have courtesy, consider the feelings of others, and enjoy peace. Furthermore, to be able to maintain justice, it must be able to follow the rules (according to the rules), like to share with others, be able to think openly, and always try to listen to others. To be able to care for others, it must have the ability to be loving, always grateful and grateful for what you have, can forgive others, and always be able to help people in need. Then to be able to be responsible, it must be able to be disciplined, have consideration before acting, have responsibility for the duties and choices taken, and be able to do the best. All of these attributes should be reflected in the Unimed students, so that 
students who study unimed should be trustworthy, able to respect others, be able to maintain justice, have care for others, be responsible for themselves and the tasks that are their responsibility.

The results of the study conducted Spencer [8] there are 19 kinds of soft skills, namely: Achievement orientation, concern for order and quality, initiative, information seeking, interpersonal understanding, customer service orientation, impact and influence, organization awareness, relationship building, developing others, directiveness, teamwork and cooperation, leadership team, analytical thinking, conceptual thinking, self control, self confidence, flexibility, organizational commitment. Furthermore, the results of Ramesh's study (2010: 5) classify soft skills into three groups which include attitude, communication, and etiquette, which is believed to be a very important three-dimensional aspect in soft skills and subsequently abbreviated as ACE. Attitude is a part related to the correct mental ownership that is used to interact with humans and the environment, as if communication is the ability to express attitudes and beliefs effectively through various forms of communication. Etiquette is a general rule that is generally accepted, in the form of noma-noma that must be followed to achieve effective communication.

Soft skills in higher education institutions in Malaysia [9] also use a number of attributes of soft skills issued by the Malaysian Ministry of Higher Education in 2006 which serves as a guide and focus on the implementation of soft skills in Malaysia including: (1) communication skills, (2) critical thinking and problem solving skills, (3) cooperation, (4) lifelong learning skills and information management, (5) entrepreneurial skills, (6) professional ethics and morals, and (7) leadership skills. Based on research conducted by British, American and Canadian countries, there are 23 dominant attributes of softskills in employment [2]. The 23 attributes are sorted based on priority interests in the world of work, namely: (1) Initiative, (2) Ethics / integrity, (3) Critical thinking, (4) Learning willingness, (5) Commitment, (6) Motivation, (7 ) Enthusiastic, (8) Reliable, (9). Oral communication, (10) Creative, (11) Analytical ability, (12) Can overcome stress, (13) Selfmanagement, (14) Resolve problems, (15) Can summarize, (16) Cooperate, (17). Flexible, (18) Work in teams, (19) Mandiri, (20) Listening, (21) Tough, (22) Logical argumentation, (23) Time management. The results of the analysis and verification of the relevance of its application to lectures for prospective teachers indicate that all attributes are relevant to be integrated in the lecture process.

Furthermore, the results of Sailah's review (2008: 19) classify various soft skills directed at interpersonal and intrapersonal grouping. Attributes belonging to intrapersonal groups such as transforming character, transforming beliefs, change management, stress management, time management, creative thinking processes, goal setting \& life purpose, and accelerated learning techniques. while the attributes grouped in interpersonal skills include: communication skills, relationship building, motivation skills, leadership skills, self-marketing skills, negotiation skills, presentation skills, public speaking skills.

The results of the validation of the level of relevance of each type of attribute found that generic soft skills have $51(91 \%)$ which are in the very relevant category, and $5(9 \%)$ which are included in the relevant category. Furthermore, specific soft skills are $69(95 \%)$ which are categorized as very relevant, and $4(5 \%)$ which are included in the relevant category. This validation activity also provides information on the suitability distribution of each type of attribute to be trained in a given year, and the results found indicate that there are 54 types of attributes that are relevant for training in the first year, 52 relevant attribute types trained in the second, and 23 relevant attribute types are trained in the third year. In detail the distribution of the number of attributes that are relevant in the first to third year is shown in Figure 1. Based on Figure 1, it is seen that specific soft skills training will be more trained in the first year, and in the second year there will be more soft skills training the genric. This is certainly very relevant, because to carry out generic training must be supported by the ability of specific soft skills.

When viewed based on the level of relevance of each type of attribute, it was also found that the results of verification showed a balance between proiritas (very relevant) soft skills trained both in the first year, second and third. The detailed results of verification of the distribution of soft skills based on their level of relevance are shown in Figure 2. Based on the study of the results of identification of the teserbut soft skills verification, it appears that quite a number of attributes can be integrated and trained in prospective teacher students to produce simultaneous teacher competencies. Based on re-validation, it is seen that there are 73 types of generic attributes and 56 types of soft skills that are specific in their entirety, including in the very relevant and relevant categories. This shows that 129 types of attributes have been found to be relevant to be used as a supplement to the lecture, so that overall they are suitable to be mapped and distributed to each subject taken by students in accordance with the characteristics of the subject matter. 


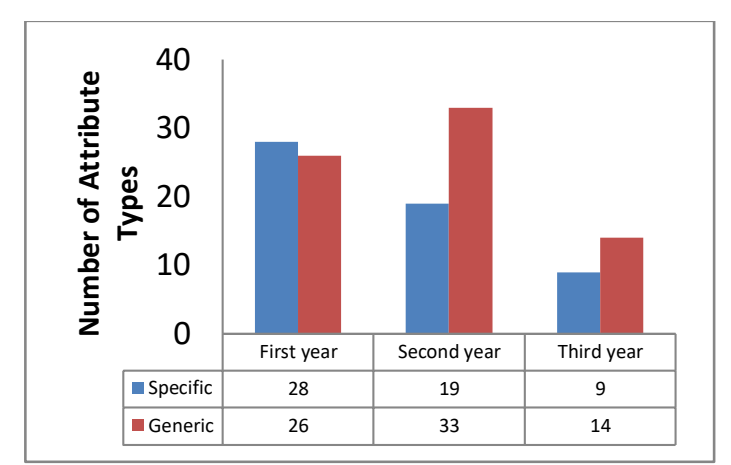

Fig 1. The Distribution Number of Attributes Relevant for Three Years

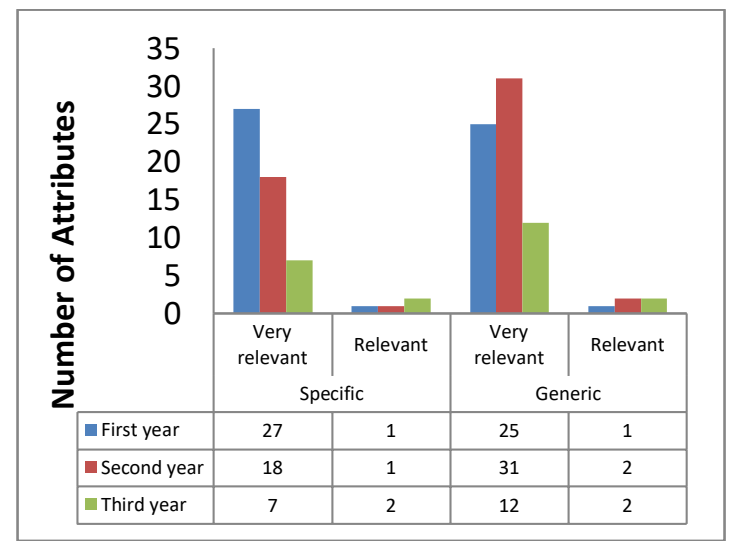

Fig 2. The Distribution Number of Attributes Relevant for Three Years Based on the Relevance Level

The many attributes of soft skills that have been identified and discussed above, it can be seen that many of these attributes have never been trained in the learning atmosphere developed in the world of higher education in Indonesia. The world of higher education in Indonesia includes the education of prospective teachers, it turns out that it focuses more on developing hard skills alone, even according to [2] that 90 percent of students get in college is hard skills and only 10 percent is in the form of soft skills, whereas based on from the discussion above, the more dominant point in determining one's success in the world of work is his soft skills. In other conditions, it shows that the world of work wants the ability of soft skills for higher education graduates. For this reason, efforts are needed to accommodate the conditions that the graduate users want through changing the curriculum or reconstructing the contents of the curriculum by accommodating the values of soft skills to be included in the current curriculum in higher education. Efforts or steps that must be done in developing the values of soft skills in universities, especially in the education of prospective teachers is to integrate soft skills in learning. This can be started from the same understanding that soft skills cannot be taught instructionally in class in the form of certain courses but soft skills can be instilled through understanding values through hidden curriculum teacher models, college visions and extra curricular activities of students who have positive values that will ultimately produce the character of students who have adequate hard skills and soft skills so that they are ready to face the world of work.

The pattern of developing soft skills in teacher education can be started from the effort to re-agree on what values (university/department values) that will be invested in students in a particular department. for example, it is agreed that the values to be instilled are discipline, honesty. cooperation, openness, high creativity, initiative and others, then there must be an effort to instill these values in the teaching and learning process and the development of an academic atmosphere that applies in the study program. These values must be mutually agreed upon and carried out jointly by the academic community. To produce the expected results there should be role models that can be used as a reference by all academics.

The process of interaction between lecturers and students in the class is the greatest opportunity to instill the values of soft skills to students, this can be done by familiarizing students to communicate more with the lecturer, discipline in obeying the rules, etc., of course this can be done by making the lecturers themselves as 
teachers models that can indeed be imitated by students. Furthermore, in this interaction process the concept of student center learning (SCL) can also be applied where students are expected to be more creative and initiative in finding lecture materials, asking questions and interacting with others.

The process of assigning class assignments can also be designed in such a way that students can judge for themselves what they are doing, or students can work together in teams to work on tasks together with the division of tasks and responsibilities clearly between themselves. Besides that the process of designing rules in class can also be done in such a way that the values of soft skills can be applied in the Department.

Learning soft skills by combining the attributes of soft skills on hard skills can be done in various ways, even according to Fogarty (2009: 10) explains that there are three models of integration in one discipline, namely fragmented models, connected models, and nested models. Model connected is a curriculum model that uses the relevance of each subject and teaching material. The integration of soft skills using a fragmented model will allow the integration of many attributes, because it allows to be divided into several subject matters. The application of soft skills integration with connected models will be more meaningful for strengthening hard skills. While the nested model is oriented towards achieving multiple skills and multiple targets. With this nested model, soft skills learning will be easily achieved, because integrated soft skills are not forced. The nested model allows learning activities to be filled with soft skills and measured through learning targets.

Soft skills are not a subject matter, but a life aspect that must be possessed by students that can be obtained from experiences that have been done. Soft skills that are considered as generic skills by Muslims et al (2012, 760) are skills that give emphasis to producing human resources needed by the State. Therefore, soft skills must be able to be explored, fostered and familiarized during the implementation of learning. The results of the study by Beard, Schwieger, \& Surendran (2008: 229) provide information that graduate users want the use of learning models that combine aspects of soft skills and their assessment in the curriculum of educational institutions. This is intended so that graduates have the relevant soft skills and work skills. Practically, the integration of soft skills into hard skills can be done through topics or units of material that are developed from the core of courses that are the parent of integration. Attributes that are integrated, of course, are attributes that are relevant to the findings and are possible to achieve. Soft skills learning is part of an effort to shape personality, therefore it requires an ongoing process as a process of civilization. Kapp and Hamilton (2006: 2) emphasize that learning soft skills requires organizing long-term learning in order to reach the stage of success. Each specific learning method to achieve certain competencies, so that it may be the type of attributes that are integrated and the way of learning one subject is not appropriate if applied to other courses, therefore the creativity of lecturers in motivating students greatly influences the success of lectures.

Based on this fact and study, all the attributes of soft skills found will be integrated in the student lectures for three years. Based on the results of identification and verification it was found that all types of attributes will be distributed to 22 courses in the first year, 22 subjects in the second, 18 subjects in the third year. The distribution of attribute types is based on the consideration of the subject lecturers based on the characteristics and types of lecture activities conducted by the lecturer. Distribution of attribute type training is also carried out gradually and continuously, so that the attributes that are trained in the first year will remain observed in the following year.

\section{Conclusion}

Based on the findings of the study, it was concluded that (1) There were 129 types of attributes that were relevant to be integrated in the prospective teacher's lecture to produce simultaneous competencies; (2) The results of verification of the types of attributes of soft skills found show that there are 120 (93\%) types of attributes belonging to the very relevant category, and $9(7 \%)$ that are categorized as relevant; (3) The verification results also show that there are 54 types of relevant attributes for training in the first year which will be distributed to 22 courses, 52 relevant attributes are trained in the second know and will be distributed to 22 courses, and 23 types of relevant attributes trained in the third year which will be distributed to 18 courses.

\section{Acknowledgments}

Thank you to the Directorate of Research and Community Service, Kemenristek Dikti which provides support, especially in the form of research funds, so that this research can be carried out well. Thanks are also conveyed 
to the Chancellor of Medan State University and his staff as well as the Chair of the Medan State University Research Institute and his staff who facilitated the implementation of this research activity well.

\section{References}

[1] Kemendiknas.: Panduan pelaksanaan pendidikan karakter. Jakarta: Kemendiknas (2011)

[2] Sailah, Illah.: Pengembangan soft skills di perguruan tinggi. Jakarta : Direktorat Jendeal Pendidikan Tinggi. (2008)

[3] Mariah, S.: Model Pengembangan Soft skills dalam pembelajaran praktik untuk kesiapan kerja siswa SMK bidang keahlian Tata Busana di industry garmen. Disertasi. Yogyakarta : Program Pascasarjana Universitas Negeri Yogyakarta. $((2012)$

[4] Zamroni.: Paradigma pendidikan masa depan. Yogyakarta:Bigraf Publishing. (2000)

[5] Irwanti,Y.D.,\& Sudira,P.: Evaluasi uji kompetensi siswa keahlian multimedia di SMK se-kota Yogyakaarta. Jurnal Pendidikan Vokasi, Vol.4. No.3, 420-433 (2014)

[6] Kapp M, K., \& Hamilton, B.: White paper:Designing Instruction to Teach Principles (soft skill). Diambil pada tanggal 2 Agustus 2012, dari http://www.karlkapp.com/materials/teaching\%20 principles.pdf. (2006)

[7] Samani, Muchlas.: Mengagas pendidikan bermakna : integrasi life skill-KBK-CTL-MBS. Surabaya : SIC. (2010)

[8] Spencer, L.M., \& Spencer, S.M.: Competency at work. New York : John Willey \& Sons Inc (1993)

[9] Shakir, R.: Soft skills at the Malaysian institutes of higher learning. Diambil pada tanggal 1 Oktober 2012, dari http://web3.fimmu.com/hsrw/vedio/book/Soft\%20skills/Soft\%20skills\%20at\%20the\%20Malaysian\%20institutes\%20of \%20higher\%20learning.pdf (2009)

[10] Ramesh, P., \& Ramesh, M.: The ACE of soft skills : attitudes, communication and etiquette for success. India : Dorling Kingdersley (India) Pvt. Ltd. (2010) 